\title{
CORRECTION
}

\section{Correction to: Computational Thinking Integration into Science Classrooms: Example of Digestive System}

\author{
Merve Arık ${ }^{1}$ Mustafa Sami Topçu²
}

Published online: 6 December 2021

(c) Springer Nature B.V. 2021

Correction to: Journal of Science Education and Technology https://doi.org/10.1007/s10956-021-09934-z

The article category of this article should be Research Article.

Publisher's Note Springer Nature remains neutral with regard to jurisdictional claims in published maps and institutional affiliations.

The online version of the original article can be found at https:// doi.org/10.1007/s10956-021-09934-z.

\section{Merve Arık}

Mustafa Sami Topçu

mstopcu@yildiz.edu.tr

1 Ministry of Education, Ankara, Turkey

2 Department of Mathematics and Science Education, Yıldız Technical University, Istanbul, Turkey 